\title{
A ten years survey of longitudinal zonation and temporal changes of macrobenthic communities in the Rhône River, downstream from lake Geneva (Switzerland)
}

\author{
M. Dethier ${ }^{1}$ \\ E. Castella ${ }^{2}$
}

Keywords : aquatic macroinvertebrates, hydropower plant, Lake Geneva, monitoring, Rhône River, Switzerland.

The macrobenthic fauna of the Rhône River below Lake Geneva was studied between 1983 and 1993 to describe patterns of longitudinal and temporal community changes. Sampling was based upon the use of artificial substrates in 11 stations. The confluence with the Arve (an alpine tributary) is the first source of faunal discontinuity, both in terms of species and feeding group composition. The Verbois hydropower plant is the second longitudinal disruption. From a temporal point of view, the construction of the Seujet hydropower plant was a major source of faunal fluctuation. After this event, and until the end of the study, lenitophilous taxa increased to the detriment of rheophilous taxa.

Etude décennale de la zonation et des variations temporelles des communautés macrobenthiques dans le Rhône, à l'aval du lac Léman (Suisse)

Mots-clés : macroinvertébrés aquatiques, barrage hydro-électrique, Lac Léman, suivi environnemental, Fleuve Rhône, Suisse.

La macrofaune benthique du Rhône, à l'aval du lac Léman (Suisse), a été étudiée de 1983 à 1993 afin de décrire son hétérogénéité longitudinale et ses variations temporelles. La macrofaune a été échantillonnée à l'aide de substrats artificiels dans onze stations. La confluence avec l'affluent alpin l'Arve est la première source de discontinuité faunistique en terme de composition taxonomique et fonctionnelle des communautés. Le barrage hydro-électrique de Verbois en est une seconde. D'un point de vue temporel, la construction du barrage hydro-électrique du Seujet a été une source majeure de variation faunistique. A la suite de cette construction et, jusqu'en 1993, on a observé une augmentation des taxons lénitophiles, au détriment des communautés plus rhéophiles.

\section{Introduction}

In the course of the last fifteen years, large rivers became a major focus, both in applied and theoretical running water research. Especially, important insights were gained in the understanding of longitudinal patterns (Ward \& Stanford 1983, Statzner \& Higler 1985),

1. Zoologie générale et appliquée. Faculté des Sciences Agronomiques. B-5030 Gembloux. Belgium.

E-mail : michel.dethier@arcadis.be

2. Laboratoire d'Ecologie et de Biologie Aquatique. Université de Genève. 18 chemin des Clochettes. CH-1206 Genève, Switzerland. and of interaction with floodplain and interstitial biotopes (Ward 1989). Concerning the invertebrate communities of large rivers, there is still a dearth of data concerning the relative importance of between-years fluctuations versus long-term changes. Such data become of critical importance for the analysis of impact or recovery processes, as demonstrated in the case of the Rhine river (Schiller 1990, Tittizer et al. 1990).

Since the end of the seventies, the Rhône river is among the most intensively studied western-European large rivers and the results obtained on this hydrosystem have contributed notable advances and methodological outputs (Amoros et al. 1987, Roux et al. 1989, Bravard et al. 1992, Statzner et al. 1994). The composition (Bournaud et al. 1982, Tachet et al. 1992, Berra- 
hou 1993), drift (Cellot \& Bournaud 1988, Cellot 1989), fluctuations and changes under human impacts (Bournaud et al. 1987a \& b, Usseglio-Polatera \& Bournaud 1989, Fruget 1991) of the macroinvertebrate assemblages have been studied in the French course of the river, but little is known proportionally about the Swiss upstream reaches.

The present study was carried out as a long term monitoring (1983 - 1993) of the macrobenthic assemblages of the Rhône River between Lake Geneva and the Swiss-French border. Its aims were : i) updating and expanding the previous data about this stretch of the river (Revaclier \& Dethier 1986, Dethier 1988a \& b, Dethier et al. 1992) ; ii) identifying the major sources of longitudinal discontinuities of the macrobenthic assemblages in the river that can be regarded here as the outlet of the lake ; iii) depicting possible changes in the faunal characteristics over a ten years period, especially in relation with the construction of an hydro-power plant located in Geneva (the Seujet weir).

\section{Study area}

Between lake Geneva and the border with France, the Rhône River flows $25 \mathrm{~km}$ in Switzerland with a slope of $1.3 \%$. The yearly average discharge is $250 \mathrm{~m}^{3} \mathrm{~s}^{-1}$ at the outlet of the lake, $337 \mathrm{~m}^{3} \mathrm{~s}^{-1}$ at the border (data 1990). Along this stretch, the more conspicuous discontinuities are, from upstream to downstream (Fig. 1) :

- the Seujet weir in Geneva, constructed between 1987 and 1994, which replaces the former Pont-de-laMachine weir, both for water level regulation and hydro-electricity production,

- the confluence with the Arve river, the first major alpine tributary of the Rhône (average discharge $77 \mathrm{~m}^{3} \mathrm{~s}^{-1}$ (data 1990) at the confluence) ;

- two releases from sewage treatment plants (Aïre and Vernier) ;

- two larger hydro-power retention dams (Verbois and Chancy-Pougny), the reservoir of which must be cleaned up every three years because of sediment accumulation.

\section{Sampling sites, sampling technique and data analysis}

Eleven sampling sites were studied (Fig. 1). Table 1 provides their general characteristics. The sampling design (Table 2) comprised two overlapping phases : a first phase (1983 - 1986) focusing on the longitudinal zonation over the whole stretch, a second phase (1985 - 1993) focusing on the temporal changes in the uppermost sites between the lake and the Arve confluence. This sampling programme was not planned initially as a whole and was influenced over the years by its immediate applied objectives. Therefore, the incompleteness of the design must be kept in mind when analysing the results.

Benthic macroinvertebrates were sampled with artificial substrates. These were cubic baskets (side 20 $\mathrm{cm})$, made with wire netting (mesh size $1 \mathrm{~cm}$ ) and filled with pebbles (diameter 3 to $6 \mathrm{~cm}$ ). Two artificial substrates (one near each bank of the river) were exposed for one month at each sampling site. Only the mean of the substrates exposed at a site will be considered subsequently in the text and called a "sample". The identification of invertebrates was carried out using the key of Tachet et al. (1984), up to the taxonomic levels required by the calculation of the French biotic index (IQBG, Verneaux et al. 1976), i.e. family or genus levels in most cases. Information at species level was gained for a large part of the material and published in Dethier (1988b). Regarding feeding groups, Oligochaeta and Chironomidae were grouped under gathering-collectors because they comprised mostly Tubificidae and Lumbriculidae for the first, Chironominae, Orthocladiinae and Diamesinae for the second.

Correspondence Analysis (CA) (Greenacre 1984) was chosen to analyse the data. A first CA was used to describe the overall faunal similarities among samples and to look for the major sources of variability in the complete data set (61 taxa, 88 samples). According to the procedure described by Dolédec \& Chessel (1989, 1991), two constrained CA were used subsequently to describe more accurately spatial and temporal variations in the data set. A between-sites CA was applied to the data subset collected prior to the beginning of the construction of the Seujet weir (July 1983 - April $1986: 10$ sites, 54 taxa, 47 samples) to concentrate on the description of the longitudinal differences between sites. A between-years CA was then applied to the data collected in the sites closely affected by the weir construction (sites 1 to 6), sampled over a longer period of time (June 1985 - August 1993 : 6 sites, 43 taxa, 55 samples), to concentrate on the description of temporal changes. In order to reduce the importance of large abundance values relative to smaller values in the data matrix, all the abundance data (mean counts per substrate for each site) were transformed into classes prior to the CA. Class $n$ is defined by : $2^{n-1}\left(x<2^{n}\right.$, where $\mathrm{x}$ is the non-transformed abundance value. All data processing and graphical outputs have been car- 


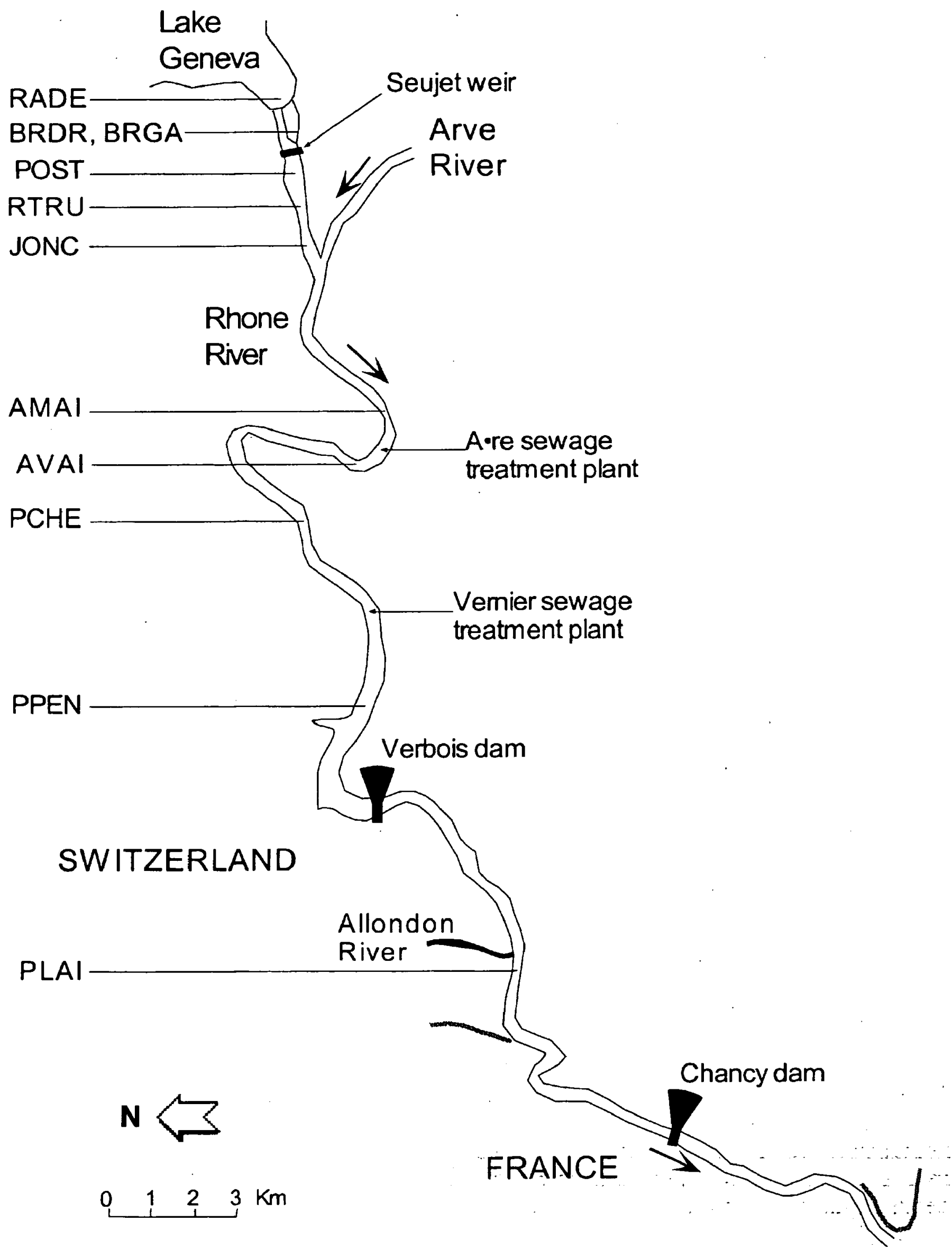

Fig. 1. The Rhône River between Lake Geneva and the French border, showing the location of the 11 sampling sites Fig. 1. Carte du Rhône entre le lac Léman et la frontière française montrant la localisation des 11 stations d'étude. 
Table 1. General characteristics of the 11 sampling sites along the Rhône River.

Tableau 1. Caractéristiques des 11 stations échantillonnées le long du Rhône.

\begin{tabular}{clllll}
\hline Station & Name & Current & Turbidity & Substrate & Pollution \\
\hline & & & & & \\
1 & Radc & slight & low & silt to pebble & null to low \\
2 & Bras droit & strong & low & gravel/pebble & null to low \\
3 & Bras gauche & moderate & low & silt to pebble & null to low \\
4 & Pont Sous-Terre & strong & low & gravel/pebble & null to low \\
5 & rue de la Truite & strong & low & gravel/pebble & null to low \\
6 & Jonction & strong & low & gravel/pebble & null to low \\
7 & amont Aïre & moderate & high & slightly silted & low \\
8 & aval Aïre & moderate & high & slightly silted & strong \\
9 & passerelle de Chèvres & slight & high & silted & moderate \\
10 & pont de Peney & null to slight & high & strongly silted & moderate \\
11 & La Plaine & strong & high & gravel/pebble & low to moderate \\
\hline
\end{tabular}

ried out using the ADE software (Thioulouse et al. 1997).

\section{Results}

\subsection{Dominant taxa and functional feeding group representation}

The macrobenthic communities of this stretch of the Rhône River were dominated by eight taxa : Oligochaeta, Chironomidae, Hydra, Hydropsyche, Gammarus, Polycentropodidae, Dugesia and Dreissena (Table 3). Each of the remaining 53 taxa represented less than $1 \%$ of the total number of individuals collected. The complete taxonomic list collected is given in table 3 with indications on the functional feeding groups.

The longitudinal pattern of functional feeding group representation evidenced three sectors along this Rhône stretch. From 1 to 6 (upstream from the Arve confluence), gathering collectors were well represented (average $59 \%$ of the individuals) but other groups, such as shredders $(20 \%)$ and predators $(15 \%)$ were also relatively abundant. Downstream from the Arve confluence ( 7 to 10$)$, gathering collectors became overabundant (average $92 \%$ of the individuals, mostly Chironomidae and Oligochaeta) and the relative proportion of the other groups reduced consequently. In the last site (11), downstream from the Verbois dam,
Table 2. Sampling design of the macrofauna.

Tableau 2. Plan d'échantillonnage de la macrofaune.

\begin{tabular}{|c|c|c|c|c|c|c|c|c|c|c|c|c|}
\hline & stations: & 1 & 2 & 3 & 4 & 5. & 6 & 7 & 8 & 9 & 10 & 11 \\
\hline years & months & & & & & & & & & & & \\
\hline 1983 & 7 & & & & & & & & & + & & + \\
\hline \multirow[t]{6}{*}{1984} & 4 & & & & & & & + & + & + & + & + \\
\hline & 6 & & & & & + & & + & + & + & + & + \\
\hline & 7 & & & & & + & & + & + & + & + & + \\
\hline & 8 & & & & & & & & & + & & + \\
\hline & 9 & & & & & & & & & + & & + \\
\hline & 11 & & & & & + & & + & + & + & + & + \\
\hline \multirow[t]{4}{*}{1985} & 6 & + & + & + & + & & & & & & & \\
\hline & 7 & & & & & & & & & + & & + \\
\hline & 9 & + & + & + & + & & & & & & & \\
\hline & 12 & + & + & + & + & & & & & & & \\
\hline 1986 & 4 & + & + & + & + & & & & & & & \\
\hline \multirow[t]{3}{*}{1988} & 3 & & + & & + & + & & & & & & \\
\hline & 7 & & + & & + & + & & & & & & \\
\hline & 10 & & + & & + & + & & & & & & \\
\hline \multirow[t]{3}{*}{1989} & 6 & & + & & & + & & & & & & \\
\hline & 9 & & + & & & + & & & & & & \\
\hline & 12 & & + & & + & + & + & & & & & \\
\hline \multirow[t]{4}{*}{1990} & 4 & & + & & + & + & + & & & & & \\
\hline & 6 & & + & & & + & + & & & & & \\
\hline & 9 & & & & & + & + & & & & & \\
\hline & 12 & & & & & & & + & + & & & \\
\hline 1991 & 8 & & + & & + & + & + & & & & & \\
\hline \multirow[t]{2}{*}{1992} & 8 & & & & + & + & + & & & & & \\
\hline & 10 & & & & + & + & + & & & & & \\
\hline 1993 & 8 & & & & + & + & + & & & & & \\
\hline
\end{tabular}


Table 3. Average abundance per artificial substrate of the taxa in the 11 sampling sites (all sampling dates combined). Feeding groups : pr - predator, gc - gathering collector, fc - filtering collector, sc - scraper, sh - shredder, pa - parasite, pi - piercer.

Tableau 3. Abondance moyenne des taxons par substrat artificiel dans les onze stations d'échantillonnage (toutes dates confondues). Groupes trophiques : pr - prédateur, gc - collecteur, fc - filtreur, sc - brouteur, sh - broyeur, pa - parasite, pi - perceur.

\begin{tabular}{|c|c|c|c|c|c|c|c|c|c|c|c|c|c|}
\hline & & & Stations & & & & & & & & & & \\
\hline & & $\begin{array}{l}\text { Feeding } \\
\text { groups }\end{array}$ & 1 & 2 & 3 & 4 & 5 & 6 & 7 & .8 & 9 & 10 & 11 \\
\hline Hydra cf. oligactis & & $\mathrm{pr}$ & 24 & .75 .7 & 10 & 41 & 148.4 & 31.9 & $\overline{6}$ & - & 52.4 & 6.75 & 394 \\
\hline NEMATHELMINTHES & & pa & $\cdot$ & 0.3 & - & - & 1.6 & 1.7 & - & - & - & $\cdot$ & - \\
\hline Dugesia spp. & & pr & 63 & 47.8 & 99 & 53.3 & 69.5 & 88.3 & 0.5 & - & - & 0.5 & - \\
\hline Polycelis gr. nigra-tenuis & & pr & 8 & 0.3 & 11.75 & 3.1 & 5 & 3.5 & 2.5 & 7.8 & 0.1 & 0.5 & 0.5 \\
\hline Dendrocoelum lacteum & & $\mathrm{pr}$ & - & 1.9 & 1.75 & 0.9 & 3.75 & 11.4 & - & - & 0.25 & - & 0.25 \\
\hline OLIGOCHAETA & & $g c-f c$ & 28 & 33.7 & 13.5 & 42.5 & 62.7 & 81.9 & 623 & 1065 & 3405 & 1714 & 234 \\
\hline Glossiphonia complanata & & $\mathrm{pr}$ & 0.5 & - & - & 0.3 & 1.35 & 1.7 & 0.16 & - & 0.25 & 1 & - \\
\hline Helobdella stagnalis & & $\mathrm{pr}$ & 0.5 & $0.3^{\circ}$ & 0.5 & 0.7 & 0.85 & 0.8 & 2.5 & 0.5 & 0.5 & 0.25 & - \\
\hline Hemiclepsis marginata & & $\mathrm{pr}$ & 0.25 & - & 0.25 & 0.05 & - & - & - & - & - & 1.5 & - \\
\hline Erpobdella octoculata & & $\mathrm{pr}$ & 4.75 & 0.8 & 3.5 & 1.5 & 1.25 & 1.2 & 0.7 & 4.8 & 6.6 & 4 & 4.9 \\
\hline Piscicola geometra & & $\mathrm{pr}$ & - & - & 0.25 & 0.25 & 0.17 & - & - & - & - & - & - \\
\hline Valvata piscinalis & & sc & - & 0.1 & $\cdot$ & - & 0.1 & - & - & - & - & - & - \\
\hline Potamopyrgus antipodarum & & sc & + & 0.15 & - & 0.2 & 0.14 & 0.45 & - & 0.16 & - & - & - \\
\hline Bithynia tentaculata & & sc & 2 & 1 & 0.5 & 2.8 & 5.2 & 7.75 & - & - & - & 0.25 & 0.5 \\
\hline Bythinella pupoides & & sc & - & - & - & - & - & - & 0.3 & - & - & - & 0.1 \\
\hline Physella acuta & & sc & 1 & 0.2 & 0.25 & 0.4 & 1.4 & 0.2 & - & 0.7 & 1 & 20.3 & 0.25 \\
\hline Radix peregra & & sc & 7.75 & 4.2 & 9.5 & 4.9 & 6.56 & 7.5 & 2 & 0.5 & 1.1 & 1.4 & 3.6 \\
\hline Planorbidae & & sc & 4.5 & 0.5 & 1.75 & 0.3 & 0.7 & 0.37 & - & 0.3 & 0.1 & - & 0.6 \\
\hline Ancylus fluviatilis & & sc & - & 0.26 & - & - & 0.3 & 0.75 & 0.16 & $0.3^{\circ}$ & - & 0.25 & 0.75 \\
\hline Sphaerium of. corneum & & fc & 1 & 0.8 & 3.5 & 0.09 & 1 & 2.4 & 0.3 & - & - & 0.5 & 0.1 \\
\hline Pisidium spp. & & fc & - & 0.4 & 3.5 & 0.15 & 1.5 & 2.5 & 4.16 & 0.3 & - & 1.75 & 1.9 \\
\hline Dreissena polymorpha & & fc & 15.75 & 13.8 & 11.25 & 36.8 & 22.6 & 43.75 & 0.5 & - & 0.1 & 0.25 & $0.7 \dot{5}$ \\
\hline HYDRACARINA & & pr-pa & - & 0.35 & - & 0.2 & 1.2 & 1.5 & 3.5 & - & - & - & $\therefore$ \\
\hline Asellus aquaticus & & sh & 4.25 & 10.2 & 3.25 & 18.5 & 18.7 & 40.3 & 3.8 & 6.3 & 1.6 & 6.3 & 0.1 \\
\hline Gammarus spp. & & sh & 164.5 & 54.5 & 70.5 & 79.4 & 77.7 & 39.9 & 268 & 173.5 & 68.4 & 49.8 & 61 \\
\hline Baetis spp. & & sc & 0.75 & 0.1 & - & 0.05 & 0.14 & - & $=$ & 0.16 & - & - & 2.6 \\
\hline Rhithrogena iridina & & sc & - & - & - & - & - & - & - & $\therefore$ & - & - & $0: 25$ \\
\hline Ecdyonurus spp. & & sc & - & - & - & . & - & - & 0.3 & 0.16 & - & $\cdot$ & 0.37 \\
\hline Heptagenia spp. . . & $\cdots$ & sc ... & $\ldots$ & - & 0.25 & 0.05 & - & - & - & - & - & 0.25 & $4: 75$ \\
\hline Ephemerella ignita & : & șh: & 0.75 & $\cdot 10^{-}$ & - & -4.2 & 29.3 & 0.9 & 1 & 0.5 & 1.9 & 0.25 & 12.1 . \\
\hline Caenis luctuosa & & sh & - & 0.05 & - & - & 0.07 & - & 0.7 & 0.5 & 1.1 & - & 0.1 \\
\hline Habrophlebia lauta & & sh & - & - & - & - & - & - & 0.16 & 0.3 & - & $\therefore$ & 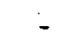 \\
\hline Brachyptera cf. risi & & sc & - & - & - & - & - & - & . - & - & - & - & 0.1 \\
\hline Amphinemura sulcicollis & & sh & - & - & - & - & - & - & 0.7 & 0.16 & 0.1 & $=$ & 0.1 \\
\hline Nemoura cf. cinerea & & sh & - & - & - & - & - & - & 0.7 & 0.3 & - & - & - \\
\hline Leuctra gr. inermis & & sh & - & - & - & - & 0.03 & - & 0.3 & 0.3 & - & - & 0.75 \\
\hline Perla cf. marginata & & pr & - & - & - & - & 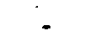 & - & - & - & - & - & 0.1 \\
\hline Riolus subviolaceus & & sc & - & - & - & - & - & - & - & - & - & - & 0.1 \\
\hline Elmis cf. maugeti & & sc & - & - & - & - & - & $\therefore$ & - & - & - & - & 0.25 \\
\hline Típulidae & & sh & - & - & - & - & 0.03 & $\therefore$ & 0.16 & - & 0.1 & - & - \\
\hline Limoniidae & & $\mathrm{pr}$ & - & 0.15 & - & - & - & - & - & - & - & - & - \\
\hline Psychodidae & & sc & - & 0.15 & - & 0.05 & 0.07 & - & 1.5 & 0.8 & 0.25 & - & - \\
\hline Simuliidae & & fc & - & 0.05 & - & - & 0.18 & $\cdot$ & 0.7 & 0.5 & 0.1 & - & 4.9 \\
\hline Chironomidae & & gc & .371 & 251 & 534 & 144 & 177 & 95.3 & 867 & 1720 & 618 & 246 & 257 \\
\hline Empididae & & $\mathrm{pr}$ & - & - & - & - & 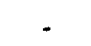 & - & 0.5 &. & 0.1 & - & - \\
\hline Tabanidae & & $\mathrm{pr}$ & - & - & - & - & - & - & 0.16 & - & 0.1 & - & - \\
\hline Anthomyidae & & $\mathrm{pr}$ & - & - & - & - & - & - & 0.3 & - & - & - & - \\
\hline Rhyacophila spp. & & pr & - & . & - & - & - & - & 1.7 & - & 0.1 & - & 3.9 \\
\hline Hydropsyche spp. &. & fc & 12 & 15 & 7.75 & 17.6 & 23.9 & 7.8 & 16.3 & 20.2 & 12.2 & 2.3 & 860 \\
\hline Hydroptila spp. & & sc & 34.8 & 3.5 & 12.5 & 19.3 & 11.8 & 15.8 & - & - & - & 0.5 & 0.1 \\
\hline Agraylea multipunctata & & pi & 3 & 3.4 & 1.75 & 0.9 & 5.8 & 4.9 & - & - & - & 0.25 & - \\
\hline Polycentropodidae & & $\mathrm{pr}$ & 88.3 & 44.6 & 91.8 & 71.5 & 88.6 & 81.6 & 15 & 16.5 & 8.4 & 5 & 5.25 \\
\hline Psychomyiidae & & fc & - & 0.3 & - & - & 0.14 & 0.12 & - & - & - : & - & - \\
\hline Limnephilidae & & sh & - & - & - & $\therefore$ & 0.1 & 0.9 & 1.8 & 1 & - & 1 & 0.1 \\
\hline Lepidostomatidae & & sh & - & - & - & - : & 0.35 & - & - & - & - & - & - \\
\hline Leptoceridae & & sh-sc-gc & 9.25 & 4.15 & 5.25 & 15.3 & 16.8 & 25.5 & 0.7 & 0.5 & 0.1 & 0.75 & 0.6 \\
\hline Sericostomatidae & & sh & 0.25 & 0.05 & - & 0.15 & 0.8 & 0.7 & - & 0.16 & 0.1 & 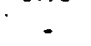 & 3.4 \\
\hline Beraeidae & & sh & 0.25 & - & 0.25 & - & 0.07 & 0.25 & - & - & - & - & - \\
\hline Ecnomus sp. & & $\mathrm{pr}$ & 0.05 & - & - & - & - & - & - & - & - & - & - \\
\hline Philopotamidae & & $\mathrm{fc}$ & - & - & - & - & - & - & 9.5 & - & - & - & - \\
\hline
\end{tabular}


filtering collectors ( $69 \%$, mostly Hydropsyche) exceeded gathering collectors ( $23 \%$ ).

\subsection{CA of the total data set}

The first factorial axis (F1) of the CA of the total data set (Fig. 2) described a separation between the samples collected downstream from the confluence with the Arve River during the first part of the survey, and the samples collected in the upper sites later on. The uppermost sites were characterized by taxa such as Dreissena, Bithynia, Dugesia, Dendrocoelum, $\mathrm{Hy}$ dracarina, Hydroptila, Agraylea and Leptoceridae, which were less abundant and frequent in the sites downstream of the confluence. These latter (except 10) were characterised by a set of rheophilic or relatively rheophilic insects occurring with low frequency and abundance, such as Ecdyonurus, Amphinemura, Leuctra, Riolus, Elmis, Rhyacophila, Empididae and Anthomyidae, these taxa being almost totally absent from the upstream sites (Table 3).

The two following factorial axes described more localized effects. Axis F2 singled out samples from site 7 , the first site downstream from the Arve confluence where several infrequent rheophilic taxa occurred (Philopotamidae, Nemoura, Ecdyonurus, Anthomyidae, Empididae). This axis also depicted the increase of taxa like Dendrocoelum and Hydracarina in sites 5 and 6 at the end of the study period (after December 1990). Axis F3 operated a clear distinction within the downstream sites ( 7 to 11 ) between the 4 sites located upstream from the Verbois dam and site 11 located downstream from the dam. In 11, a set of rheophilic taxa occurred, the more constant of which were Heptagenia and Baetis, associated with the less frequent Brachyptera, Rhithrogena, Elmis, Riolus, Perla and Rhyacophila. In contrast, Caenis, Physella, Limnephilidae, Ceratopogonidae, Psychodidae, Tabanidae, and Habrophlebia characterized the macrobenthic assemblages upstream from the Verbois dam (7 to 10). Axis F3 also evidenced what can be regarded as temporal fluctuations within the upper sites ( 1 to 6 ).

\subsection{Between-sites CA}

The between-sites CA was designed to discriminate the sites in the data set collected until April 1986, before the construction of the Seujet weir. The first ordination plane from this analysis (Fig. 3) described $59 \%$ of the inertia of the data set and evidenced three groups of sites corresponding to three successive sectors of the Rhône stretch:

- Sector I : from the lake to the Arve confluence (sites 1 to 5 ). The current velocity reaches $1.25 \mathrm{~ms}^{-1}$ and the average suspended load is around $7 \mathrm{mgl}^{-1}$, the bottom substrate is coarse (pebbles and cobbles). The macrobenthic assemblage was composed of a mixture of taxa drifted out of the lake but able to settle in the Rhône, and of taxa living on substrates covered with filamentous algae (e.g. Dugesia, Piscicola, Dreissena, Hydroptila, Agraylea, Lepidostomatidae).

- Sector II : from the Arve confluence to the Verbois dam (sites 7 to 10). The current velocity is lower (maximum around $0.45 \mathrm{~ms}^{-1}$ ) and the average suspended load is around $17 \mathrm{mgl}^{-1}$. The separation between this set of sites and the previous one along the first axis of the between-sites CA evidenced the Arve confluence as a major source of faunal discontinuity. Especially, this discontinuity appeared to be more important than the impact of the release from the Aire sewage treatment plant (between sites 7 and 8). However, a gradient of faunal changes could be described from 7 to 10 along the $\mathrm{F} 2$ axis. It was associated with the decrease or disappearance of rheophilous or lithophilous taxa such as Nemoura, Amphinemura, Leuctra, Habrophlebia, Hydropsyche, Simuliidae ; simultaneously lenitophilous taxa such as Physella increased.

- Sector III : it comprised the single site 11 located downstream from the Verbois dam. It was characterized by the restoration of a more rheophilous and lithophilous assemblage. Some of the taxa which disappeared or were less abundant in sector two resettled here (Dendrocoelum, Baetis, Ancylus, Sericostomatidae). Additionally, a set of taxa typical for large and relatively fast flowing rivers occurred, but with a low abundance : Perla, Leuctra, Brachyptera, Heptagenia, Rhithrogena, Ecdyonurus, Rhyacophila, Elmis and Riolus.

\subsection{Between-years CA}

The between-years CA was designed to describe the temporal changes in the macrobenthic assemblages for the six sites upstream from the Arve confluence ( 1 to 6), for which the longest time series had been obtained (June 1985 to August 1993). The first ordination plane from this analysis (Fig. 4) described $54 \%$ of the inertia of the data set. The first CA axis (F1) separated the last three years (1991 to 1993) from the previous years of the study, these first five years were then ordinated along the second CA axis (F2), with the exception of 1986 and 1988. Thus, the temporal changes of the macrobenthic assemblages could be described as follows:

The two pre-construction years $(1985,1986)$ were well grouped. They were characterized by the occurrence of infrequent taxa (Baetis, Hemiclepsis, Heptagenia), associated with the typical fauna of this stretch (Hydroptila, Hydropsyche, Gammarus, Asellus). The 

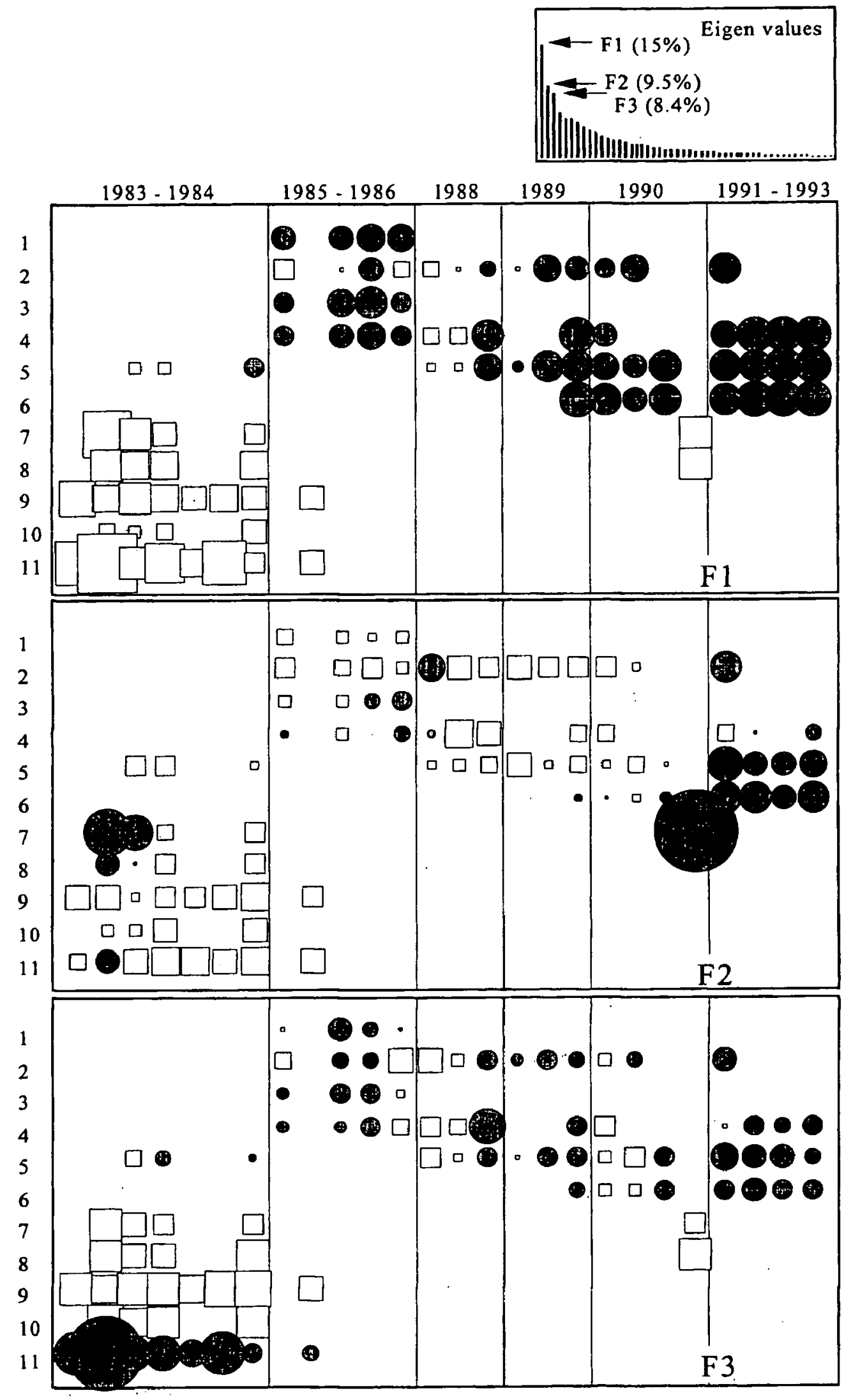

Fig. 2. Factorial scores of the samples along the first three axes of the Correspondence Analysis applied to the total data set. Scores for each sample are plotted as squares (negative values) or circles (positive values) on the sampling design chart (see Table 2). The surface area of the squares and circles is proportional to the absolute value of the corresponding factorial score. The percentage of inertia explained by each axis is given.

Fig. 2. Coordonnées factorielles des échantillons sur les trois premiers axes factoriels issus d'une Analyse Factorielle des Correspondances appliquée aux données complètes. Les coordonnées factorielles sont représentées sous forme de carrés (coordonnées négatives) ou de cercles (coordonnées positives) de taille proportionnelle à leur valeur absolue sur la grille spatio-temporelle décrivant le plan d'échantillonnage (voir Tableau 2). Les pourcentages d'inertie expliqués par chaque axe sont indiqués. 

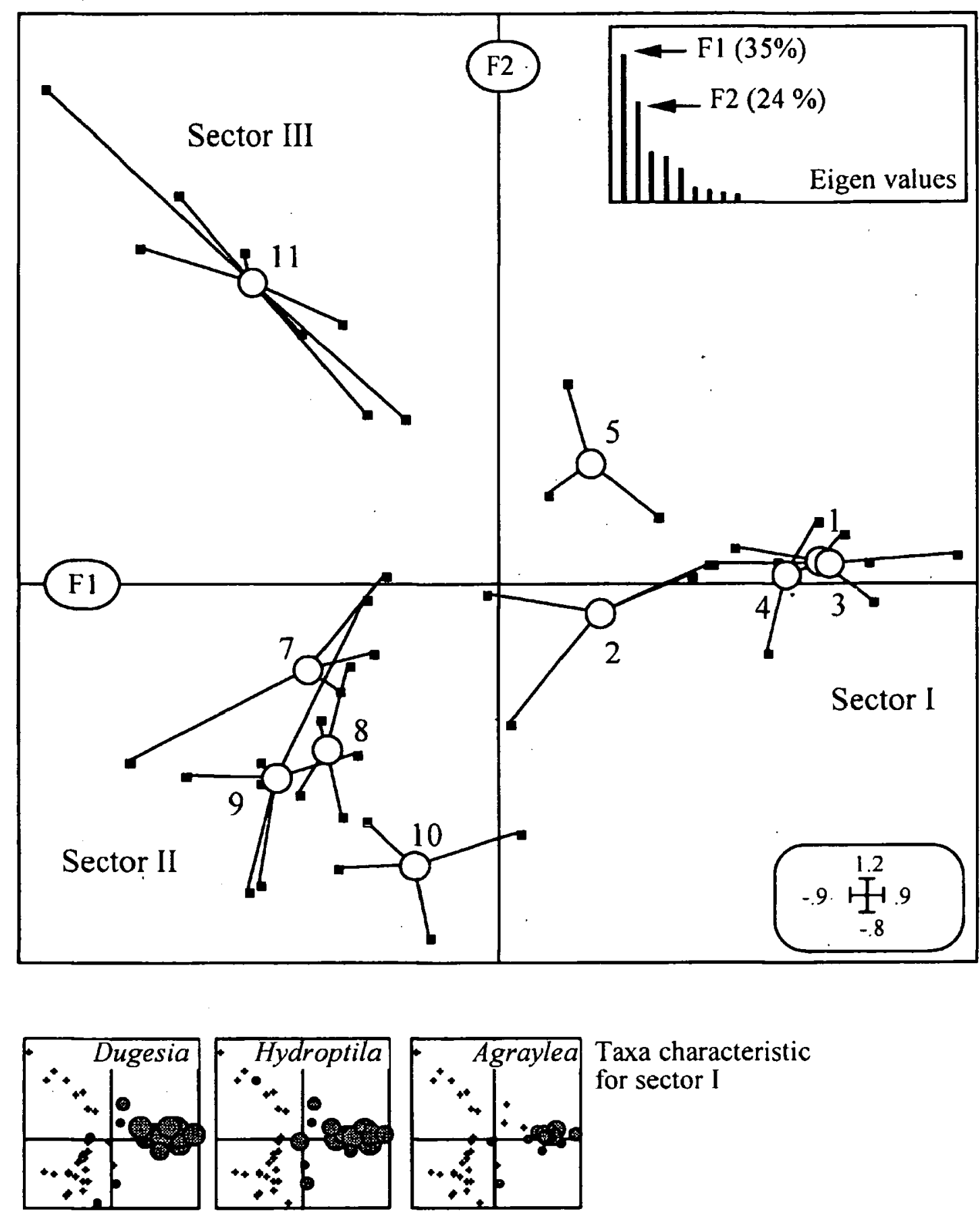

Taxa characteristic for sector I
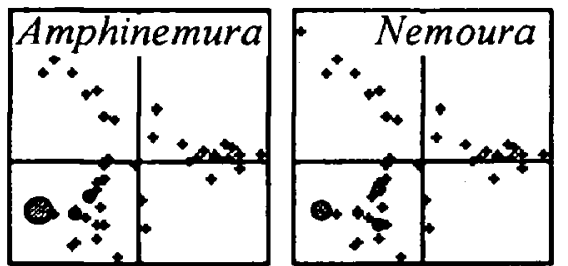

Taxa characteristic

for sector II
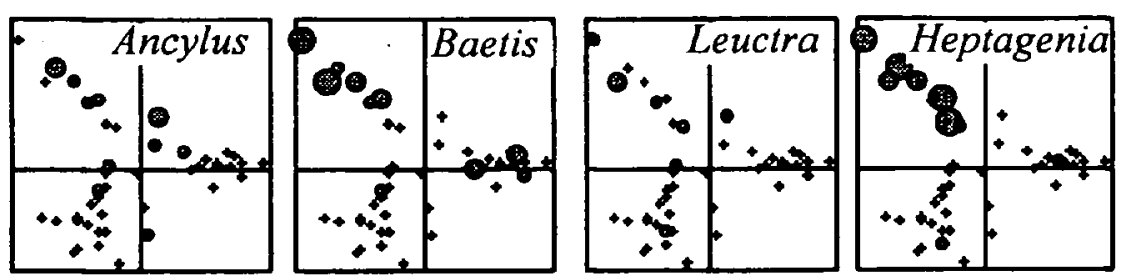

Taxa characteristic for sector III

Fig. 3. Above : first factorial plot of the samples in the between-site Correspondence Analysis. Small squares represent the samples. Each site (open circle) is positioned at the weighted average of samples representing that site.

Below : the abundance of 9 taxa is plotted as examples on the same factorial plot. The surface area of the circles is proportional to the abundance of the taxa. Crosses denote samples where the taxon is missing.

Fig. 3. En haut : premier plan factoriel des échantillons dans l'Analyse Factorielle des Correspondances inter-stations. Chaque site est représenté par un cercle situé au centre de gravité des positions des relevés (petits carrés) qui lui correspondent.

En bas : représentation de l'abondance de 9 taxons choisis comme exemples, sur le même plan factoriel. Les cercles sont de taille proportionnelle aux effectifs des taxons dans les relevés. Les croix indiquent les relevés où le taxon est absent. 

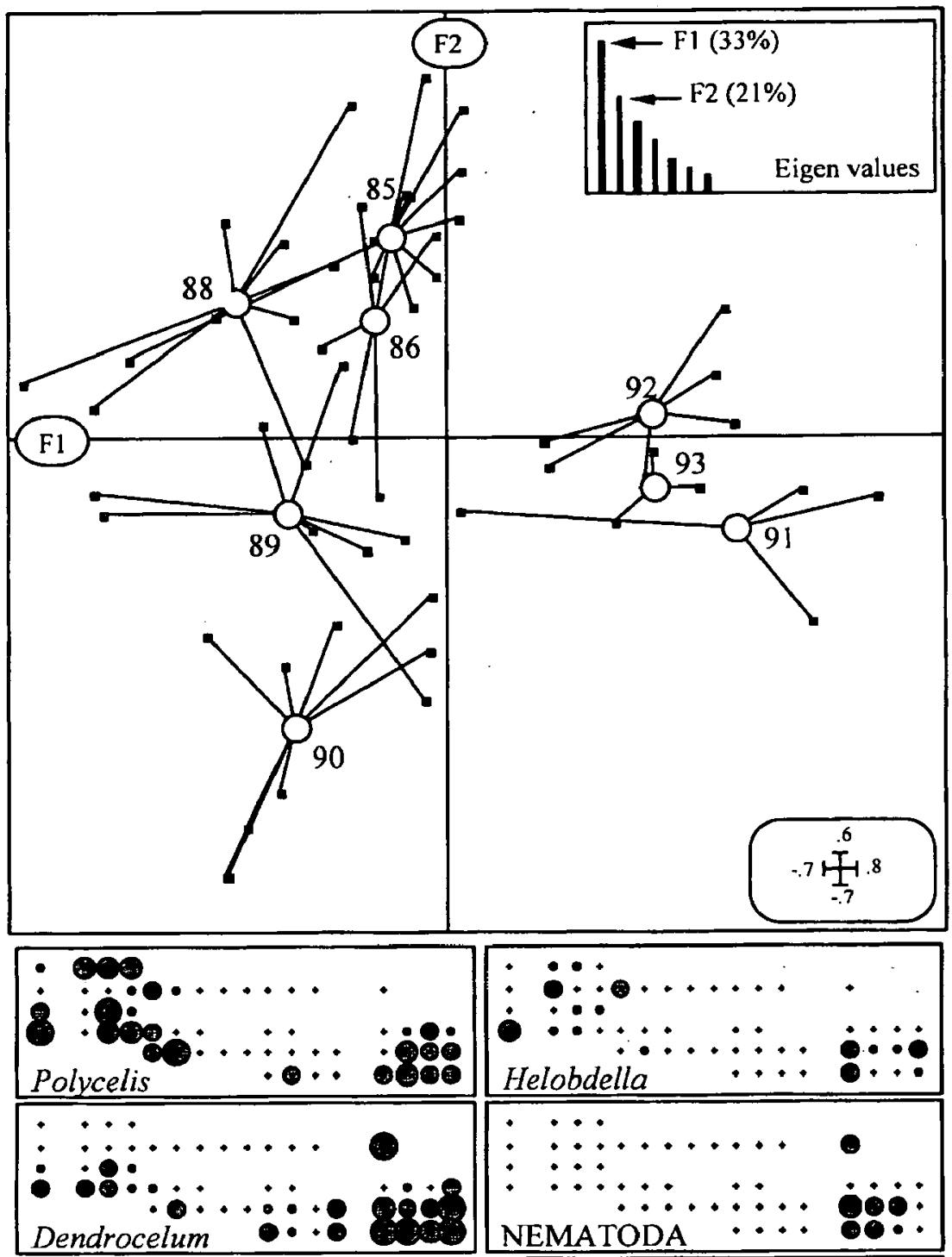

Helobdella
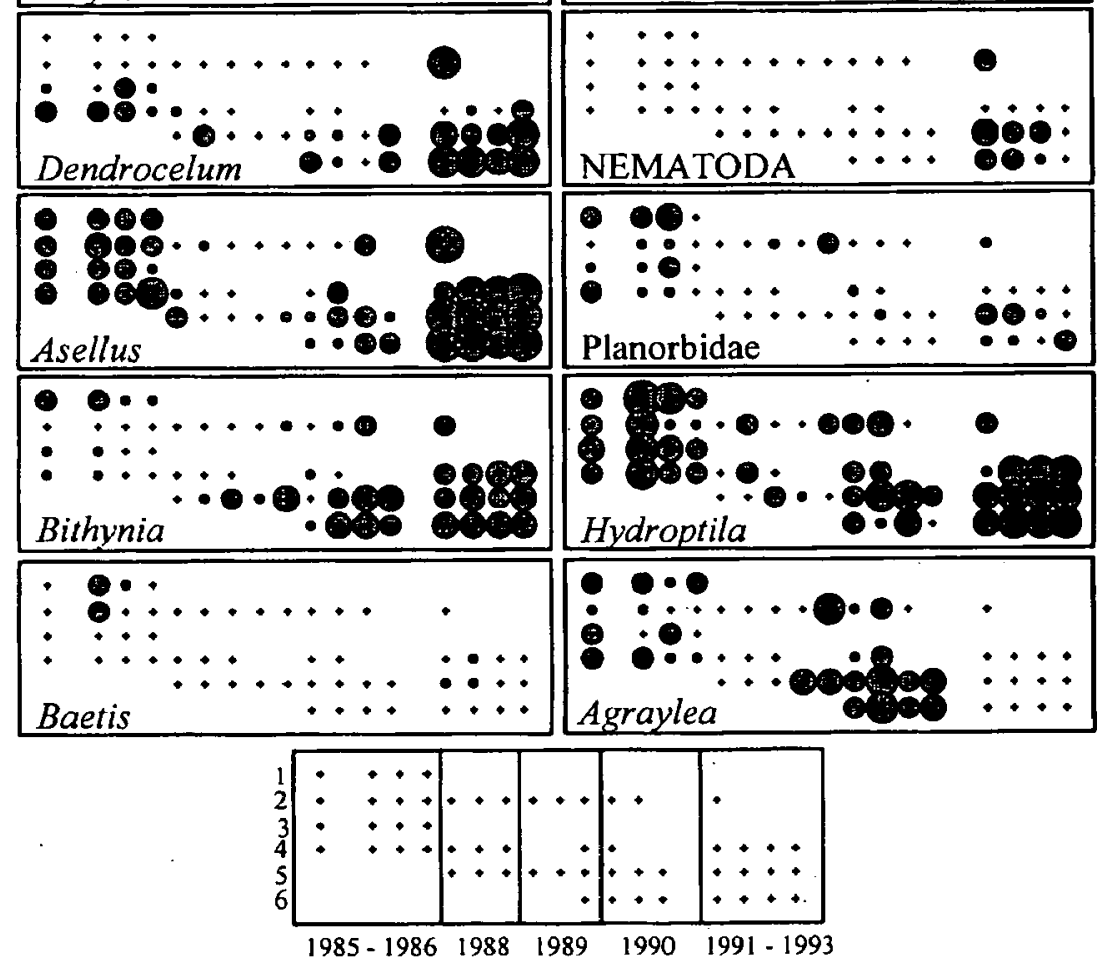

Fig. 4. Above : first factorial plot of the samples in the between-year Correspondence Analysis. Line segments group samples belonging to the same year. Below: the abundance of 10 taxa with characteristic temporal abundance variations, is plotted on the sampling design chart. The surface area of the circles is proportional to the abundance of the taxa. Crosses denote samples where the taxon is missing.

Fig. 4. En haut : premier plan factoriel des échantillons dans l'Analyse Factorielle des Correspondances inter-dates. Les segments de droite associent les échantillons appartenant à une même année. En bas : représentation de l'abondance de 10 taxons sur la grille spatio-temporelle décrivant le plan d'échantillonnage. Les cercles sont de taille proportionnelle aux effectifs des taxons dans les relevés. Les croix indiquent les relevés où le taxon est absent. 
three years following the beginning of the construction of the weir $(1988,1989,1990)$ were then departing progressively from the pre-construction period (shift along the F2 axis). The transition between the two sampling dates April 1986 and March 1988, which coincided with the beginning of the works, represented a major discontinuity for the occurrence of taxa such as Asellus, Planorbidae, Hydroptila or Agraylea (Fig. 4). Some others decreased only after the end of 1988 (Polycelis, Helobdella). 1990 evidenced the recovery of Asellus. Finally, a major change was evidenced between 1990 and the three following years (1991 to 1993) which appeared also well grouped on the F1 CA axis. The recovery of taxa like Polycelis, Helobdella, Baetis, Planorbidae, the noticeable increase of lenitophilous taxa such as Asellus, Bithynia, Hydroptila and Dendrocoelum and the occurrence of Nematodes (Fig. 4), were responsible for this individualization of the final period.

\section{Discussion}

The macrobenthic assemblages recorded along the Swiss stretch of the Rhône downstream from Lake Geneva evidenced two important longitudinal discontinuities. The first one is the confluence with the Arve River, the first major alpine tributary of the Rhône. The Arve carries a high suspended load and its bed is largely siltated, hence it has a relatively low faunal richness (Berrahou 1993). The clogging of the Rhône River bed by the Arve sediments has a natural component (eroding activity of the Arve River) but is also amplified by two anthropogenous factors : the release of fine sediments from the gravel extractions along the Arve, and the deposition of these sediments in the Verbois reservoir. Bed sediment clogging strongly reduces habitat quality and availability for the macrofauna, furthermore fine sediments trap toxic substances $\left(\mathrm{N}-\mathrm{NH}^{4}\right.$, heavy metals) released either by the Aire sewage treatment plant, or by metallurgic industries located in the Arve valley. Therefore, the impact of the Arve River on the Rhône is strong, causing the desappearance or sharp reduction of taxa such as Dugesia, Planorbidae, Dreissena, Agraylea, Hydroptila or Leptoceridae downstream from the confluence. Not only has the Arve an impact in terms of species composition, but also in terms of functional composition of the communities. Between the lake and the Arve confluence, the water is clear and enables the development of submerged macrophytes, which support the development of significant shredder assemblages. The important role of vegetation fragments drifted out from the lake must also be acknowledged for the support of these shredders communities, especially in summer when large areas of lake littoral hydrophyte beds are cut for weed control. Thus, this stretch of the Rhône River maintains a relatively diversified community, except a rather low representation of scrapers. Downstream from the Arve, the functional feeding group diversity is considerably reduced. This effect is amplified by the release from the Airre sewage treatment plant, the main and classical consequence of which is an increase in macroinvertebrate abundance and a simultaneous decrease in taxonomic richness.

The Verbois dam causes the second major faunal discontinuity. The lenitic conditions in the reservoir amplify the deterioration of the water quality caused by the Aire sewage treatment plant. Furthermore, daily and weekly oscillations of the water level induced by the Verbois plant operations worsen the life conditions in the river littoral zone. Downstream from the dam, the previous tendancies are cancelled, leading to a different and richer community dominated by filtering collectors (mainly Hydropsyche). The increase of filtering collectors downstream from dam releases has already been documented (Williams 1981, Petts 1988) and associated with an increased seston transport. Berrahou (1993) also observed this in the French stretch of the Rhône at Pougny, some few kilometres downstream from site 11. However, some features of the situation observed here downstream from the Verbois dam contrast with the patterns more commonly observed downstream from hydropower plant releases (see for example Brittain \& Saltveit 1989, Garcia de Jalon et al. 1994). Although the increase of taxa such as Baetis and Ephemerella can be expected in stabilised flow conditions (Brittain \& Saltveit 1989), the downstream station 11 evidences the concomitant increase or appearance of rheophilic taxa, usually dependent upon good environmental quality, that are not expected to occur in such conditions (the mayfly Heptagenia, the stonefly Brachyptera, Leuctra and Perla). The occurrence of these taxa could also be explained by faunal inputs from the Allondon River. Some of the species (especially among the Trichoptera) drifting out of this good quality river can certainly settle in the Rhône and contribute to the recovery of its fauna downstream from the Verbois dam.

From a temporal point of view, the construction of the Seujet weir was a source of major faunal fluctuations in the uppermost sites. The three years (1988 to 1990) following the beginning of the construction works were characterized by a sharp reduction of the taxonomic richness in the sites located both immediately upstream (site 2) and downstream (sites 4 and 5) 
from the building site. The reduction is extremely conspicuous during the first construction year, due to the intense perturbation of the river : release of suspended matters, modification of flow directions, increase of flow velocity induced by the narrowing of the river section. Especially in 1988, a high amount of organic sediment was suddenly washed out of the left side arm of the Rhône (site 3 ), which had a very slow water velocity prior to the work. Extreme variations of water discharge and velocity were also common during this year (from 53 to $525 \mathrm{~m}^{3} \mathrm{~s}^{-1}$ between January and August 1988). The recovery was then progressive in 1989 and 1990 when such drastic variations tend to reduce. The state of the community observed during the last study phase differs from the pre-construction situation. Although taxa like Polycelis or Dendrocoelum obviously recovered, the more stable flow conditions between 1991 and 1993 led to an obvious increase of lenitophilous taxa such as Bithynia, Asellus or Hydroptila.

\section{Acknowledgements}

We thank the "Service de l'Ecotoxicologue Cantonal" of Geneva, and especially MM. Hurni and J.C. Gardey for assistance in the field and laboratory works, as well as the "Département des Travaux Publics" of Geneva for lending boats during the sampling operations. We thank MM. Bournaud, H. Tachet (Lyon), B. Lods-Crozet (Geneva), and two anonymous reviewers for helpful comments on the manuscript.

\section{Reference}

Amoros C., Roux A.L., Reygrobellet J.L., Bravard J.P. \& Pautou G. 1987. - A method for applied ecological studies of fluvial hydrosystems. Regulated Rivers, $1: 17-36$.

Berrahou A. 1993. - Répartition longitudinale des macroinvertébrés benthiques du Rhône français et sa relation avec les principaux affluents. Thèse de Doctorat. Université Lyon $1: 133 \mathrm{p}$.

Bournaud M., Tachet H. \& Perrin J.F. 1982. — Les Hydropsychidae (Trichoptera) du Haut-Rhône entre Genève et Lyon. Ann. Limnol., $18: 61-80$.

Bournaud M., Tachet H., Roux A.L. \& Auda Y. 1987a. - The effects of seasonal and hydrological influences on the macroinvertebrates of the Rhône River, France. I. Methodological aspects. Arch. Hydrobiol., 109 : 287-304.

Bournaud M., Tachet H. \& Roux A.L. 1987b. - The effects of seasonal and hydrological influences on the macroinvertebrates of the Rhône River, France. II. Ecological aspects. Arch. Hydrobiol., Suppl. $76: 25-51$.

Bravard J.P., Roux A.L., Amoros C. \& Reygrobellet J.L. 1992. The Rhône River : a large alluvial temperate river. In The rivers handbook Vol. 1, Calow,P. \& Petts G.E. (eds) Blackwell Scientific Publications, Oxford : 426-447.

Brittain J.E. \& Saltveit S.J. 1989. - A review of the effect of river regulation on mayflies (Ephemeroptera). Regulated Rivers, 3 : 191-204.

Cellot B. 1989. - Macroinvertebrate movements in a large European River. Freshwat. Biol., 22 : 45-55.
Cellot B. \& Bournaud M. 1988. - Dynamique spatio-temporelle des déplacements de macroinvertébrés dans une grande rivière. Can. J. Zool., 66 : 352-363.

Dethier M. 1988a. - Les macroinvertébrés benthiques du Rhône genevois. I. Aspects méthodologiques et indices de qualité biologique globale. Bull. mens. Soc. Lin. Lyon, 57 : 261-280.

Dethier M. 1988b. - Les macroinvertébrés benthiques du Rhône genevois. II. Aspects faunistiques. Revue suisse Zool., 95 : 1117-1131.

Dethier M., Balikungeri A., Revaclier R. \& Landry J.C. 1992. Qualité biologique, chimique et bactériologique du Rhône. Rapp. Comm. int. prot. eaux Léman contre pollut., Campagne 1991 : 169-204.

Dolédec S. \& Chessel D. 1989. - Rythmes saisonniers et composantes stationnelles en milieu aquatique. II. Prise en compte et élimination d'effets dans un tableau faunistique. Acta Oecologica.,10: 207-232.

Dolédec S. \& Chessel D. 1991. - Recent developments in linear ordination methods for environmental sciences. Advances in Ecology, $1: 133-155$.

Fruget J.F. 1991. - The impact of river regulation on the lotic macroinvertebrate communities of the lower Rhône, France. Regulated Rivers : $6: 241-255$.

Garcia de Jalon D., Sanchez P. \& Camargo J.A. 1994. - Downstream effects of a new hydropower impoundment on macrophyte, macroinvertebrate and fish communities. Regulated Rivers, 9 : 253-261.

Greenacre M.J. 1984. - Theory and application of Correspondence Analysis. Academic Press : 363 p.

Petts G.E. 1988. — Impounded Rivers. Perspectives for ecological management. J. Wiley \& Sons, Chichester : $326 \mathrm{p}$.

Revaclier R. \& Dethier M. 1986. - Etude écologique du Rhône genevois (1983-1986). Gas - Wasser - Abwasser, 66 : 756-764.

Roux A.L., Bravard J.P., Amoros C. \& Pautou G. 1989. - Ecological changes of the French upper Rhône River. In Historical changes of large alluvial rivers in Western Europe. Petts G.E., Möller H. \& Roux A.L. (eds) J. Wiley \& Sons, Chichester : 323-350.

Schiller W. 1990. - Die Entwicklung der Makrozoobenthonbesiedlung des Rheins in Nordrhein-Westfalen im Zeitraum 1969-1987. Limnologie aktuell, 1 : 259-275.

Statzner B. \& Higler B. 1985. - Questions and comments on the River Continuum Concept. Can. J. Fish. Aquat. Sci., 42 : 1038-1044

Statzner B., Resh V.H. \& Roux L. 1994. - The synthesis of longterm ecological research in the context of concurrently developed ecological theory : design of a research strategy for the Upper Rhône River and its floodplain. Freshwat. Biol., 31 : 253-263.

Tachet H., Bournaud M. \& Richoux P. 1984. - Introduction à l'étude des macroinvertébrés des eaux douces. Université Lyon 1, Association Française de Limnologie : 150 p.

Tachet H., Pierrot J.P., Roux C. \& Bournaud M. 1992. - Net-building behaviour of six Hydropsyche species (Trichoptera) in relation to current velocity and distribution along the Rhône River. $J$. N. Am. Benthol. Soc., 11 : 350-365.

Thioulouse J., Chessel D., Dolédec S. \& Olivier J.M. 1997. — ADE$4:$ a multivariate analysis and graphical display software. Statistics and Computing, $7: 75-83$.

Tittizer T., Schöll F. \& Schleuter M. 1990. - Beitrag zur Struktur und Entwicklungsdynamik der Benthalfauna des Rheins von Basel bis Diusseldorf in den Jahren 1986 und 1987. Limnologie aktuell, 1 : 293-317. 
Usseglio-Polatera P. \& Bournaud M. 1989. - Trichoptera and Ephemeroptera as indicators of environmental changes of the Rhône River at Lyon over the last twenty-five years. Regulated Rivers, $4: 249-262$.

Verneaux J., Faessel B. \& Malesieux G. 1976. - Note préliminaire à la proposition de nouvelles méthodes de détermination de la qualité des eaux courantes. Trav. Lab. Hydrobiol. Université Besançon \& CTGREF : $14 \mathrm{p}$.

Ward J.V. 1989. - The four-dimensional nature of lotic ecosystems. J. N. Am. Benthol. Soc., $8: 2-8$.
Ward J.V. \& Stanford J.A: 1983. - The serial discontinuity concept of lotic ecosystems. In Dynamics of lotic ecosystems, Fontaine T.D. \& Bartell S.M. (eds), Ann Arbor Sci. : 29-42.

Williams D.D. 1981. - Migrations and distributions of stream benthos. In "Perspectives in running water ecology" Lock \& Williams, Plenum. Press, New York : 155-207. 